\title{
FEATURES OF CRIMINAL PROCEEDINGS (PRE-TRIAL AND TRIAL INVESTIGATION) IN THE TIME OF PANDEMIC COVID-19
}

CARACTERÍSTICAS DE LOS PROCESOS PENALES (INVESTIGACIÓN PREVIA AL JUICIO Y JUICIO) EN EL MOMENTO DE LA PANDEMIA COVID-19

\author{
Larysa Bielik \\ Olena Samoilenko** \\ Hanna Mudretska ${ }^{* * *}$ \\ Tetiana Voloshanivska ${ }^{* * * * *}$ \\ Kateryna Titunina ${ }^{* * * * *}$
}

Abstract: The work is devoted to the main problems and features that have emerged in the field of criminal justice (pre-trial investigation and trial) in a pandemic. The relevance of this article is that criminal justice, like other areas of human activity, has been affected after the spread of Covid-19 and its recognition as a pandemic. The introduction of quarantine was accompanied by some problematic issues, including uncertainty in the work

\footnotetext{
* Ph. D., Associate Professor of Department of Forensics of National University "Odesa Law Academy" (Odesa, Ukraine). https://orcid.org/00-0003-2183-6635. larysa.bielik1@gmail.com

** Ph. D., Associate Professor of Department of Forensics of National University "Odesa Law Academy" (Odesa, Ukraine). https://orcid.org/0000-0002-8925-4116. samoilenko_elena@ukr.net

*** Ph. D., Associate Professor of Odessa State University of Internal Affairs (Odesa, Ukraine). https://orcid.org/0000-0002-8203-1710. mudrezkaya@ukr.net

***** Ph. D. (c) of the Department of Criminal Procedure of Odesa State University of Internal Affairs (Odesa, Ukraine). https://orcid.org/0000-0002-1060-5412.

t.voloshanivska@gmail.com

${ }^{* * * * *} \mathrm{Ph}$. D., leading researcher of the Interagency Organized Crime Research Centre at the National Security and Defense Council of Ukraine (Kiev). https://orcid.org/0000-00032800-345X.k.titunina@mvs.gov.ua
} 
of the judiciary and law enforcement agencies, lack of a unified approach to court schedules, and the conduct of certain investigative actions. Thus, it is necessary to analyze the peculiarities of criminal proceedings in a pandemic. An explorative and collative methodology (that considers the comparative law) was used. The proposals have been made to address the problems that arise during the pre-trial investigation and criminal proceedings in a pandemic, in particular: the need to allow videoconferencing in criminal proceedings out of court; a list of programs for video communication have been defined; to provide adequate funding for technical re-equipment; to suspend the terms of criminal proceedings, and; to prevent in the future the situation of cancellation of previously adopted decisions on the strengthening of criminal liability for intentional infection.

Keywords: Criminal Proceedings, Covid-19, Pre-Trial Investigation, Quarantine, Human Rights and Freedoms

Resumen: El artículo analiza los principales problemas y características que han surgido en el campo de la justicia penal (instrucción y juicio) durante la pandemia. La relevancia del tema es que la justicia penal, al igual que otras áreas de la actividad humana, se ha visto afectada tras la propagación del Covid-19 y su reconocimiento legal como pandemia. La aprobación de medidas de cuarentena estuvo acompañada de algunas cuestiones problemáticas, incluida la incertidumbre en el trabajo del poder judicial y los organismos encargados de hacer cumplir la ley, la falta de un enfoque unificado para los horarios de los tribunales y otros aspectos de la investigación. Por ello, resulta necesario analizar las peculiaridades del proceso penal (instrucción y juicio) durante una pandemia. Para el efecto, se utilizó una metodología exploratoria y colativa que toma en cuenta el derecho comparado. Se han hecho propuestas para abordar los problemas que surgen durante la investigación previa al juicio y los procesos penales en una pandemia, en particular: la necesidad de permitir la videoconferencia en los procesos penales fuera de los tribunales; se ha definido una lista de programas para la comunicación por video; proporcionar fondos adecuados para el reequipamiento técnico; suspender los términos del proceso penal, y; prevenir en el futuro la situación de anulación de decisiones previamente adoptadas sobre el fortalecimiento de la responsabilidad penal por infección intencional.

Palabras clave: Procedimientos criminales, Covid-19, investigación previa al juicio, cuarentena, derechos humanos y libertades 
Summary. I. Introduction. II. Analysis of recent research. III. Results and discussion. III.1. International and National Law Governing Criminal Proceedings. III.2. Changes in the legislation governing the procedure of criminal proceedings in a pandemic. III.3. Features and main problems of criminal proceedings at the stage of pre-trial investigation. III.4. Features and main problems of criminal proceedings at the stage of the trial. IV. Conclusions. References.

\section{INTRODUCTION}

Many international legal acts protect the right to access to justice as one of the fundamental rights that man needs in modern society. Given the provisions of international treaties, states seek to establish judicial systems that operate based on justice, legality, independence and impartiality. The construction of such a system is impossible without proper legal regulation of the judicial process, which must be constantly improved because of the conditions in which society is developing.

The outbreak of acute respiratory disease Covid-19 in early 2020 and its recognition as a pandemic necessitated the introduction of certain quarantine measures at the regional level. It has become clear that there is a threat of restrictions on human rights, including the right of access to justice. To mitigate the consequences of such a restriction, the state and judicial authorities must develop mechanisms that will ensure access to justice for everyone, even in quarantine.

As a result of the rapid implementation of such mechanisms, serious problems and inconsistencies have arisen, affecting not only the judiciary and law enforcement agencies but also the public. To ensure the rights and freedoms of man and citizen in our society, the state must take care of the proper functioning of these bodies. That is why the question of inventing the best options for solving existing problems in the field of criminal justice have arisen.

After a while, we received confirmation of some of our fears in the statistics of the direct impact of the pandemic and quarantine measures on the activities of law enforcement agencies (Table 1). 
Table 1. The performance indicators of investigative bodies and prosecutors

\begin{tabular}{cccc}
\hline Month of 2020 & $\begin{array}{c}\text { Criminal cases } \\
\text { initiated }\end{array}$ & $\begin{array}{c}\text { Investigation } \\
\text { suspicions presented }\end{array}$ & $\begin{array}{c}\text { Prosecutor's } \\
\text { office indictments }\end{array}$ \\
\hline January & 140290 & 35778 & 19981 \\
February & 178079 & 63641 & 40908 \\
March & 133299 & 39513 & 25386 \\
April & 153663 & 54993 & 38771 \\
May & 195580 & 71106 & 57924 \\
June & 215956 & 86308 & 72211 \\
\hline
\end{tabular}

Figure 1. The performance indicators of investigative bodies and prosecutors 2020

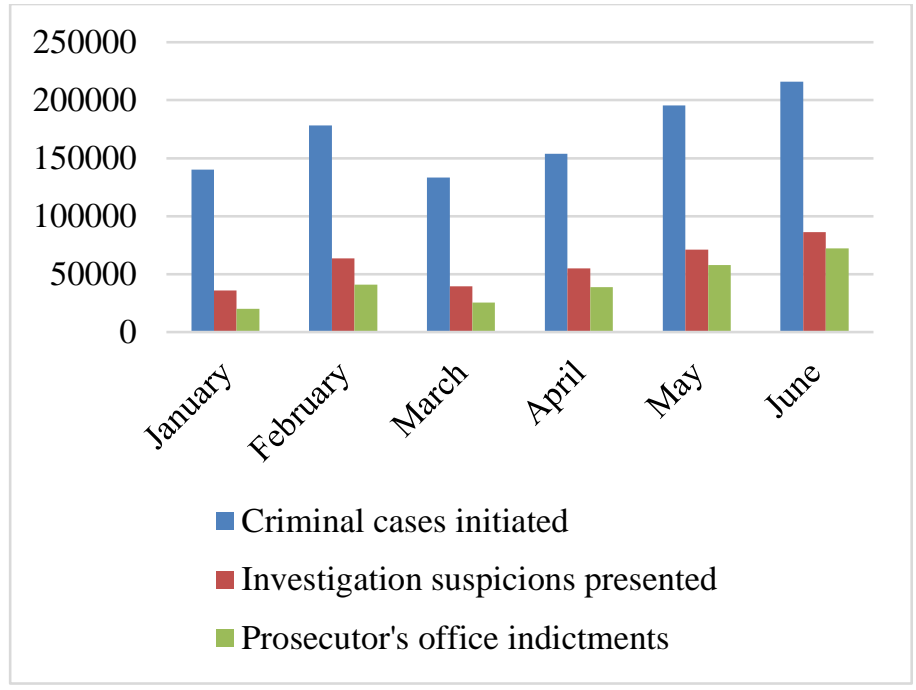

We can compare it with the indicators of 2019 for the same period:

Table 2. The performance indicators of investigative bodies and prosecutors

\begin{tabular}{cccc}
\hline Month of 2019 & $\begin{array}{c}\text { Criminal cases } \\
\text { initiated }\end{array}$ & $\begin{array}{c}\text { Investigation } \\
\text { suspicions presented }\end{array}$ & $\begin{array}{c}\text { Prosecutor's } \\
\text { office indictments }\end{array}$ \\
\hline January & 150906 & 42145 & 21362 \\
February & 160480 & 57939 & 29338 \\
March & 169692 & 63724 & 35012 \\
April & 193490 & 69949 & 44890 \\
May & 208797 & 80223 & 48959 \\
June & 218425 & 79583 & 54185 \\
\hline
\end{tabular}


Figure 2. The performance indicators of investigative bodies and prosecutors 2019

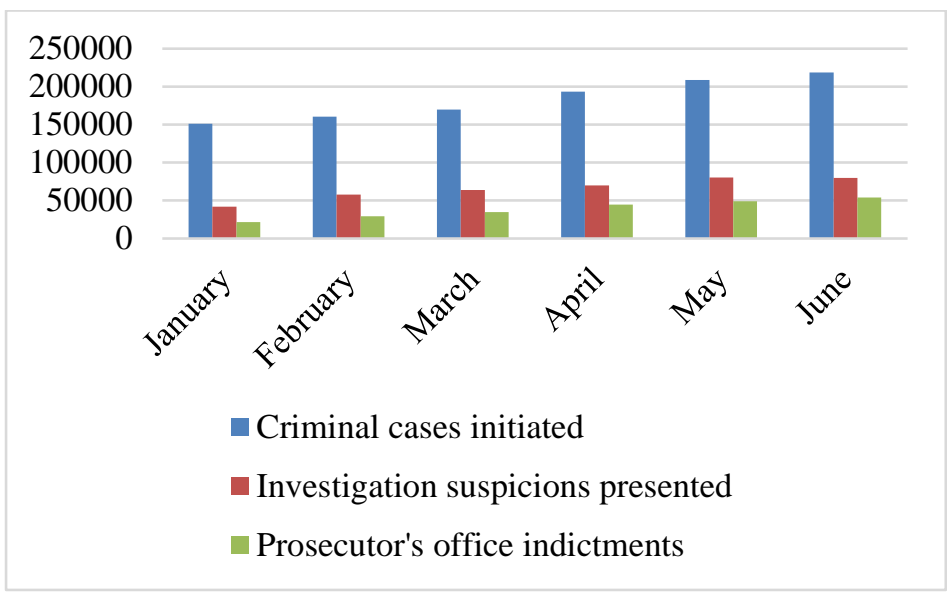

As we can see from these data, there is a significant drawdown in work in the period from March to April. It fell by about $20 \%$ from the norm (from the same period last year) in quantitative terms and by $8 \%$ in qualitative terms (the ratio of handed suspicions to the total number of criminal cases initiated). This is due to:

- self-isolation of law enforcement officers;

- interruptions in the work of other state institutions, the inability to obtain operational information; and,

- forced work in quarantine measures (not only operatives but everyone in general: investigators, forensic medical experts, technicians).

All this, of course, had a negative impact on the solution of cases and the protection of citizens from crimes.

\section{ANALYSIS OF RECENT RESEARCH}

The issue of criminal justice has been studied by many scholars who have contributed to the solution of existing problems in this area.

Thus, the works of Chernychenko (2013), Nazaruk and Kovaleva (2017), Serdyuk (2016), Turanjanin and Radulovic (2020) were devoted to the solution of the main problematic issues in the sphere of criminal justice.

Thus, Chernychenko (2013) analyzed the problematic issues of ensuring the basic principles of criminal proceedings during the proceedings by videoconference in the work "Peculiarities of the implementation of certain principles of criminal proceedings in Ukraine during video 
conference". It was emphasized that such a mechanism is a very positive practice, despite certain peculiarities of its implementation, and all the principles of criminal proceedings are observed in the implementation of proceedings by videoconference.

Besides, Nazaruk and Kovaleva (2017) in their work also investigated the peculiarities of criminal proceedings by videoconference. In particular, the article "Videoconferencing regime in criminal proceedings: advantages and disadvantages" analyzed the advantages and disadvantages of such a mechanism at the stage of pre-trial investigation. In conclusion, the researchers pointed to a large number of positive aspects of conducting a pre-trial investigation by videoconference and noted ways to solve the problem in this area.

Moreover, Serdyuk (2016) investigated the introduction of electronic justice in Ukraine. In particular, the work "Regulatory and legal support for the introduction of electronic justice in Ukraine" argued the need to develop a holistic approach to solving general and related problems of legal support for the institution of electronic justice, and accentuated the positive consequences of such an institution in Ukraine.

Among foreign scholars, the issue of criminal justice during the pandemic was analyzed, in particular, by Turanjanin and Radulovic (2020). In their article "Coronavirus (Covid-19) and Possibilities for Criminal Law Reaction in Europe: A Review", the researchers analyzed the experience of criminal justice during the pandemic in Europe. In particular, the expediency of introducing liability for violation of quarantine rules from a procedural point of view was considered.

Thus, we can say that despite the presence of a significant number of works by domestic scientists in this field, the issue of criminal justice during the pandemic has not yet been thoroughly investigated. Given that in modern conditions, due to the introduced quarantine restrictions, several changes have been made to the criminal procedure legislation, it is important to analyze the problems that have arisen in this area and consider solutions.

\section{RESULTS AND DISCUSSION}

\section{III.1. International and National Law Governing Criminal Proceedings}

To build the rule of law and the welfare state, several conditions must be met, including ensuring the rights and legitimate interests of citizens, the rule of law in all spheres of state and public life, fair and lawful pre-trial investigation and trial. To do this, in particular, it is necessary to establish a 
benchmark for compliance and implementation of international regulations in the field of criminal justice.

The Universal Declaration of Human Rights (1948) enshrines the fundamental right of everyone to the effective restoration of his or her rights by the competent national courts in case of a violation. Besides, Articles 10 and 11 define the basic principles of the administration of justice: presumption of innocence, trial by a fair, independent and impartial tribunal, legality (there is no crime without reference to it in law).

The Convention for the Protection of Human Rights and Fundamental Freedoms (1950) complements this list with such general principles as reasonable time, openness of court proceedings, except as provided by law, public sentencing, protection of the right to defense, adversarial proceedings.

The regulation of the sphere of ensuring the rights of the defendant has received special attention in the international legal field. In particular, the Minimum Standard Rules for the Treatment of Prisoners of 30 August 1955 enshrine the right to protection of persons who have been arrested or detained without charge. Under Principle 13 of United Nations (UN) General Assembly Resolution 43/173 of 9 December 1988 "Code of Principles for the Protection of All Persons Detained or Imprisoned in Any Way", any person at the time of or after detention must be explained the rights and how a person can exercise those rights.

If we talk about national law, to harmonize it, the legislator has very accurately and in detail prescribed the existing principles of criminal justice in international law. Article 55 of the Constitution of Ukraine (1996) provides that everyone is guaranteed the right to appeal in court against decisions, actions, or omissions of public authorities, local governments, and officials. It also enshrines the right of everyone to professional legal assistance, the presumption of innocence, the prohibition to prosecute twice for the same offense, the freedom to expose oneself, and the right not to testify against close relatives and family members.

The main law regulating the procedure for pre-trial investigation and trial is the Criminal Procedure Code of Ukraine (2012). In Article 7 it stipulates that the content and form of criminal proceedings must comply with the general principles of criminal proceedings, which include, in particular: access to justice and the binding nature of judicial decisions; publicity; publicity and openness of court proceedings and its full recording by technical means; reasonable timing.

Important guarantees of justice are also established by the Law of Ukraine "On the Judiciary and the Status of Judges" (2016), in particular, 
consideration of the case by a fair and competent court, equality before the law and the court, the right to review and appeal, the language of the proceedings.

Numerous bylaws are adopted for the full and accurate implementation of the principles enshrined in-laws and international acts in the field of criminal justice. In particular, the Regulation on Investigative Units of the National Police of Ukraine, approved by the Order of the Ministry of Internal Affairs of Ukraine dated July 6, 2017, No 570, establishes the main tasks of pre-trial investigation bodies, including the protection of individuals, society and the state from criminal offenses; protection of the rights, freedoms and legitimate interests of participants in criminal proceedings; ensuring a prompt, complete and impartial investigation of criminal offenses under the jurisdiction of the investigative bodies of the National Police.

Certain issues of organizing and conducting a pre-trial investigation are disclosed in the Resolutions of the Plenum of the Supreme Court of Ukraine. For example, problematic issues of sending complaints against decisions of inquiry bodies, investigators, prosecutors on the initiation of criminal cases and their solutions are described in the Resolution of the Plenum of the Supreme Court of Ukraine "On some issues of initiation of a criminal case" of June 4, 2010 No 6.

Thus, we can talk about a really detailed legal regulation of criminal justice in Ukrainian law. Procedural codes and laws enshrine the most important principles while protecting the fundamental rights of citizens. However, in the new context of recognizing the coronavirus as a pandemic, the legislator was tasked with resolving new aspects of existing public relations as soon as possible. The need for rapid decision-making and the unwillingness of Ukrainian judicial and pre-trial bodies to make drastic changes have led to serious problems in the field of criminal justice.

\section{III.2. Changes in the legislation governing the procedure of criminal proceedings in a pandemic}

Before analyzing the features of criminal proceedings due to the coronavirus, it is necessary to consider the provisions of the law governing this issue.

The provisions of the European Court of Human Rights (ECHR) in Article 15 provides for the possibility for a Member to derogate from certain of its obligations under the Convention for the Protection of Human Rights and Fundamental Freedoms (1950), but only to the extent required by the 
severity of the situation, and provided that such measures do not conflict with other obligations under international law.

According to Article 64 of the Constitution of Ukraine, the constitutional rights and freedoms of man and citizen may not be restricted, except as provided by the Constitution itself. In conditions of martial law or state of emergency, certain restrictions on rights and freedoms may be established, indicating the term of these restrictions. According to paragraph 14 of part 1 Article 92 of the Constitution of Ukraine, the proceedings are determined exclusively by law. When adopting new or amending existing laws, it is not allowed to reduce the scope of existing rights and freedoms, and exceptions to this general rule may take place only in the event of martial law or a state of emergency.

The Resolution of the Cabinet of Ministers of Ukraine "On Prevention of Spread of Acute Respiratory Disease Covid-19 Caused by SARS-CoV-2 Coronavirus" on March 11, 2020 No 211 (with further changes) was introduced throughout Ukraine. Its provisions have largely affected the rights of citizens, their access to judicial and law enforcement agencies, the work of such bodies, as well as the implementation of certain procedural actions.

The Law of Ukraine "On Protection of the Population from Infectious Diseases" (2020) regulates the implementation and operation of quarantine, and, in particular, provides for the possibility of establishing temporary restrictions on the rights of individuals and legal entities and imposing additional obligations on them.

On March 16, 2020, in his Letter, № 9rs-186/20, the Chairman of the Council of Judges of Ukraine, Monich recommended establishing a special regime of courts for the period until April 3, 2020. It was advised to refrain from attending court hearings if the hearing did not require attendance, and from going to court if there were signs of any viral illness; for citizens and other persons - to submit documents to the court remotely, to submit to the court applications for consideration of cases in their absence according to the materials available in the case, to refrain from visiting the court premises.

The High Council of Justice (HCJ) in its Decision of March 26, 2020, No 880/0/15-20 provided recommendations to the courts on the administration of justice and recommended:

- continuous administration of urgent cases, which are determined by procedural codes and courts (judges);

- if possible, to hold court hearings in real-time via the Internet;

- for the duration of the quarantine to organize a flexible schedule of judges and court staff, the meeting of judges to establish the rotation 
of judges to resolve urgent procedural issues and urgent cases in special proceedings;

- restrict access to court hearings of persons who are not participants in the proceedings;

- to hold court hearings with the use of personal protective equipment by judges and parties;

- to switch to e-mail processing, and;

- to inform the participants of court proceedings of the possibility of postponing the consideration of cases in connection with quarantine measures.

In addition, the HCJ decided to appeal to the public authorities with proposals to amend the procedural codes, which would ensure the right of individuals to access to justice in quarantine.

Thus, the Verkhovna Rada of Ukraine (Ukrainian Parliament) gradually made appropriate amendments to the Civil Procedure Code of Ukraine (2004), the Commercial Procedural Code of Ukraine (1991), the Code of Administrative Procedure of Ukraine (2005), and the Criminal Procedure Code of Ukraine. Law "On Amendments to Clause 20-5 of Section XI "Transitional Provisions" of the Criminal Procedure Code of Ukraine on Peculiarities of Judicial Control over Observance of Rights, Freedoms, and Interests of Persons in Criminal Proceedings and Consideration of Certain Issues During Judicial Proceedings Period of Quarantine Of Ministers of Ukraine in order to prevent the spread of coronavirus disease (Covid-19)" of April 13, 2020, No 558-IX amended Article 135 of the Criminal Procedure Code of Ukraine and provides for the possibility of holding a court hearing at the pre-trial and trial stages of criminal proceedings by videoconference.

Thus, the laws and clarifications introduce certain changes regarding the implementation of criminal proceedings in Ukraine in a pandemic, in particular, the possibility of holding court hearings by video conference. It is recommended:

- to restrict access to court hearings of persons who are not participants in the case, to establish a flexible work schedule of courts;

- to use personal protective equipment when visiting judicial institutions, and;

- citizens were asked to submit all necessary documents to the courts remotely online.

Nevertheless, some changes have caused new problems in the field of criminal justice, which we will consider below. 


\section{III.3. Features and main problems of criminal proceedings at the stage of pre-trial investigation}

Let us now analyze some features of the proceedings at the stage of pre-trial investigation. Thus, the main problem was the lack of amendments to the Criminal Procedure Code of Ukraine, which would regulate the suspension of procedural terms during the quarantine. As a result, investigators were forced to normally apply to investigate judges for an extension of the pre-trial investigation. As a reason, it was pointed out that the established quarantine restrictions do not allow to carry out necessary investigative actions. In addition, given the difficulties in coming to court due to restrictions on public transport, investigators are immediately asked to consider the petition without their participation. Considering that in some areas the investigating judges were significantly overworked even before the epidemic, so investigators must try to get permission for urgent investigative actions until late at night in a live queue (Communication Department of the National Police, 2020; Suk, 2019), the numerous petitions for the continuation of the pre-trial investigation due to quarantine restrictions had an extremely negative impact on system operation as a whole.

We can also talk about the slowdown in all structures that may be involved in the pre-trial investigation. Courts, the prosecutor's office, and expert institutions work in a reduced mode. The same happens in other public and private organizations. Under such conditions, investigators spend more time obtaining the necessary information and carrying out certain procedural actions (Bars, 2020).

There are also some difficulties in conducting investigative actions. In particular, since a large number of companies and government agencies have switched to remote operation mode, conducting a search and enforcing a decision to grant temporary access to things and documents is difficult. Thus, it is obvious that the investigator will be able to conduct such investigative actions only of those companies and bodies that have continued to operate as usual. This may have the effect of violating the principle of equality before the law and the courts (Shapran, 2020). To eliminate such inconsistencies, it is necessary to develop a unified approach at the legislative level to conduct certain investigative actions in a pandemic and to make appropriate changes to the Civil Procedure Code of Ukraine. Besides, by making appropriate changes, it is also necessary to solve the problem of adjusting the terms for the period of quarantine restrictions.

In Italy, for example, a law was passed introducing a "freeze period". This means that all trials that should be conducted during this period (except for the extremely important ones) are postponed to the dates after the 
quarantine restrictions have been lifted, and all procedural terms (in particular, the pre-trial investigation) are extended for the duration of such quarantine (Fisyn \& Kostrikova, 2020).

Public contact with all law enforcement agencies was also limited. Thus, on March 13, 2020, the Office of the Prosecutor General suspended the reception of citizens in the prosecutor's office and temporarily restricted the access of the population to the administrative buildings of the prosecutor's office. On March 16, 2020, the National Anti-Corruption Bureau of Ukraine restricted the work of citizens' receptions and completely switched to written communication. The National Police of Ukraine and the Security Service of Ukraine did the same.

This schedule of law enforcement agencies violates the guidelines of their activities, which provide for "accessibility" and "openness" of these bodies. To eliminate such a violation, it is necessary to establish an opportunity to establish communication with these authorities: the creation of a hotline for communication with citizens, the organization of reception of citizens via video link at a certain time. Besides, it is necessary to inform the population at the state level about all possible ways of communication with law enforcement agencies.

As Jennings and Perez (2020) rightly point out in their article "The Immediate Impact of Covid-19 on Law Enforcement in the United States" in many US states, law enforcement agencies did the same as in Ukrainerestricting the entrance of citizens. However, in addition, those wishing to report the offense were advised to either call or fill out online applications on the relevant sites. Scholars also point to the need to further develop the field of online communication between law enforcement agencies and the public, as this will significantly reduce paperwork and speed up the response to offenses.

Besides, the problem of staff shortages in law enforcement agencies, in particular, the National Police, is critical. For example, in the first weeks of quarantine, there were not enough employees to control the order in transport, and therefore everyone was involved-forensic scientists, investigators, operational units. The solution to this problem may be to increase funding for law enforcement agencies, and to develop programs that provide certain motives for employees of such bodies (Bars, 2020).

Problems also arose due to increased liability for violating quarantine rules. In particular, the Law "On Amendments to Certain Legislative Acts of Ukraine Aimed at Preventing the Occurrence and Spread of Coronavirus Disease (Covid-19)" of March 17, 2020, No 530-IX amended the Code of Ukraine on Administrative Offenses and the Criminal Code of Ukraine, which introduced administrative and increased criminal liability for 
violating quarantine rules. However, the "Final Provisions" section clearly states that the term of strengthening criminal liability is 3 months. In such a short time it is extremely difficult to carry out the necessary investigative actions, conduct the case in court and pass sentence. Thus, even though such changes have a justified and positive purpose - to force citizens to comply with the rules of quarantine and prevent the spread of the disease, we can talk about the negative consequences of their introduction. This is, in particular, the demotivation of law enforcement officers who are forced to conduct a pre-trial investigation of an offense that the court simply will not have time to consider; excessive burden on courts and pre-trial investigation bodies.

A similar problem was faced in the Russian Federation (2020), where a bill was signed amending the Criminal Code to establish criminal liability for violating quarantine rules. However, such changes were not foreseen, which helped to avoid the negative consequences described above.

To prevent the recurrence of such situations in the future, the legislator needs to be more careful in making changes to the legislation, to analyze the possible consequences, positive and negative aspects of such implementations.

\section{III.4. Features and main problems of criminal proceedings at the stage of the trial}

The implementation of criminal proceedings in a pandemic has several features (due to quarantine restrictions), the schedule of enterprises, courts, and other institutions, and in connection with which there are certain problematic issues.

As mentioned above, the investigating judge or court has the right to decide to hold a court hearing by videoconference, except when the court hearing is on consideration of a request for extension of detention, in which the suspect (accused) is outside the courtroom, if suspect (accused) objects. The court hearing is held by videoconference on the terms specified by the Criminal Code. The participation of a defense counsel in a court hearing is ensured following the requirements of the Criminal Code. The decision to hold a court hearing by videoconference may be made by an investigating judge, a court on its initiative or at the request of a party to criminal proceedings, except for consideration of a request to choose a measure of restraint in the form of detention.

However, in contrast to the amendments to the Law "On Amendments to Certain Legislative Acts of Ukraine Aimed at Providing Additional Social and Economic Guarantees in Connection with the Spread of Coronavirus 
Disease (Covid-19)" of March 30, 2020, No 540-IX, to the Commercial, Civil Procedural Codes and the Code of Administrative Procedure of Ukraine, and which provided for the possibility of participants in such cases to participate in a court hearing by videoconference outside the court using their own technical means - the Criminal Code was not amended. Thus, the purpose of Law No 558-IX, which is given to prevent the spread of coronavirus disease, is leveled, because a person must still come to the relevant court at his place of residence, especially since the share of criminal cases accounts for a significant part of cases. The data are the following: 7600 administrative cases; 29900 criminal cases; 25100 civil cases; 10900 business cases (Safir, 2020). The percentage is clearly illustrated in the diagram.

\section{Figure 3. Number of cases examined in court using videoconference}

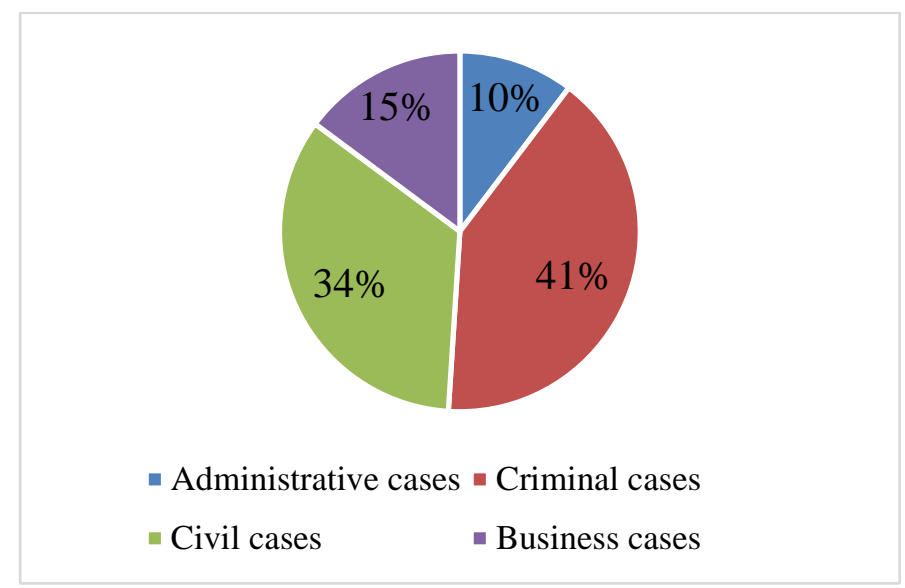

The lack of a single platform for videoconferencing in criminal proceedings also raises some issues. Thus, the Order of the State Judicial Administration of Ukraine of April 23, 2020, No 196 approved the "Procedure for working with technical means of videoconferencing during a court hearing in administrative, civil and commercial proceedings with the participation of parties outside the court", which provides for the use of EasyCon in economic, civil and administrative proceedings. The introduction of this system is a positive step towards the so-called digitalization of the court, and the system itself is quite convenient and easy to use. In addition, the relevant institutions have created special instructions for its use.

It should be noted, however, that this Procedure also provides for the possibility of video conferencing using not only the system "EasyCon", but 
also to use other programs such as Zoom, Skype, TrueConf. The courts have the right to choose the most convenient ways to establish communication, and the Procedure only provides a recommendation on the use of the "EasyCon" system. For some reason, only the procedure of videoconferencing in criminal proceedings was left out of consideration. Earlier it was reported that on April 30, 2020, the pilot project of the ecriminal system "eCase" would be launched. National Anti-Corruption Bureau of Ukraine, Specialized Anti-Corruption Prosecutor's Office, and the Supreme Anti-Corruption Court of Ukraine (anti-corruption authorities) should have been the first to check it (Office of the Prosecutor General, 2020). However, so far this system is still in the testing phase.

Also, it can be noted that one of the problems of videoconferencing in criminal proceedings is insufficient logistics of courts. This is evidenced, in particular, by the refusal to hold a court hearing by videoconference due to lack of technical capacity. Many cases are constantly postponed for this reason. For example, the request to hold a court hearing by videoconference was repeatedly denied and the date was postponed for almost a month, as decided by the Decision of the Zhovtnevyi District Court of Kryvyi Rih, Dnipropetrovsk region of August 19, 2020, in the case No 212/5119/20. Besides, as a rule, only $30 \%$ of courtrooms are provided with appropriate technical equipment in courts by videoconference. Due to this, the queues to book a hall for the month ahead are constantly growing (Safir, 2020).

To overcome the existing problems of holding court hearings in criminal proceedings by videoconference, state and judicial bodies need to take several decisive measures. Thus, the introduction of a single, albeit alternative, videoconferencing system, which could be used with its technical means, would promote respect for the rights of all participants in court proceedings and prevent the spread of coronavirus disease. And the introduction of a state program to provide courts with technical equipment to ensure quality and clear communication would help speed up criminal proceedings.

However, compared to some countries, our partially functioning system still looks good. In France, for example, courts have suspended cases other than the most important, including cases involving detainees; children; eviction of perpetrators of domestic violence. In the United Kingdom, similarly, after the introduction of general quarantine, only urgent cases are heard, for example, criminal offenses, but only if they continue for no more than three days. The European Court of Human Rights has also reduced the number of cases and only deals with disputes whose cessation will lead to "irreparable damage" (Safir, 2020). Thus, in these jurisdictions, criminal 
proceedings in some categories of cases continue, but with the peculiarities of court visits, while others are suspended altogether, which is usually forced, but still a violation of citizens' rights to a court.

Let's now consider the problems that arise with the use of the subsystem "Electronic Court". The Law of Ukraine "On the Judiciary and the Status of Judges" assign the issue of e-justice to the State Judicial Administration of Ukraine. According to the Order of the State Judicial Administration of Ukraine of June 1, 2020, No 247 "On the introduction into the trial operation of the subsystems Electronic Court and Electronic Cabinet" in all local and appellate courts of Ukraine (except the Kyiv Court of Appeal) and the Administrative Court of Cassation of the Supreme Court the functioning of these subsystems was introduced. The Electronic Court subsystem should ensure the exchange of procedural documents in electronic form between courts, bodies, and institutions of the justice system, between the court and the participants in the trial and between the participants in the trial (Ukraine, 2020, Electronic court).

Of course, the introduction of this subsystem in the courts, as well as the possibility of conducting court hearings by videoconference, is a positive step, which eliminates unnecessary bureaucracy in the courts, speeds up the processing of necessary documents, and reduces paperwork. In addition, in the context of the spread of coronavirus disease and the introduction of quarantine measures, the participants in the trial were able to send all the necessary documents to the court without leaving home. However, in practice, it is clear that not everyone has the technical ability to submit all the necessary documents through this system. Even though the digitalization of the country continues to grow, the number of internet users lags behind European levels:

- Cities with a population of more than 100,000 inhabitants (74\%);

- Settlements from 10,000 to 100,000 inhabitants (70\%); and,

- Villages up to 10,000 (58\%) (Economic truth, 2019).

Of course, in such a situation, villagers become the most vulnerable category of the population. In the so-called "village courts", many participants in the trial do not have computers, and a large part of the population is not informed about this possibility at all (Legal Newspaper, 2020). The way out of this situation can be to properly inform the public about the possibility of submitting all necessary documents to the court online, including by mobile phone.

According to foreign scholars Chawinga, Khumbo Kapondera, Chipeta, Majawa, and Nyasulu (2019), in Malawi, a small African country, there is a well-developed e-justice system since the 2000s. Special web portals offer various types of services, such as submitting evidence and 
documents to the court online, conducting court hearings by videoconference, searching for the necessary information on the case.

\section{CONCLUSIONS}

Thus, the study gives grounds to talk about the limitations of many principles of criminal proceedings during the Covid-19 pandemic. Publicity and openness of the trial, access to justice, and legality were limited. In addition, there were certain related problems requiring urgent attention, including:

1. The impossibility of conducting court hearings in criminal proceedings by videoconference outside the court premises using their own technical means eliminates the main purpose of amending the Civil Procedural Code to combat Covid-19- to prevent the spread of this disease. The solution to this problem may be to amend the legislation, which will allow in such exceptional cases to hold video conferences outside the court.

2. The lack of a single working system to provide video communication to the parties to a criminal case is a major obstacle to conducting videoconferences outside the courtroom. Therefore, public and judicial authorities should either formally launch such a national system or clarify which other platforms (Zoom, Skype, or TrueConf) may be used for this purpose.

3. Insufficient material and technical support of courts lead to the fact that some requests for a court hearing by videoconference are rejected, namely the hearing is postponed. To speed up the resolution of criminal cases, to ensure high-quality and clear communication during the conference, it is necessary to implement a program of court funding in terms of providing appropriate equipment.

4. The introduction of the e-Court subsystem is certainly a positive step that has helped to avoid unnecessary court visits to provide the necessary documents for the quarantine period, but there is still much work to be done to improve it. Due to the lack of information and logistics of some categories of the population, it is necessary to inform citizens about the possibility to apply to the court online, including through mobile phones.

5. The cessation of the reception of citizens by some pre-trial investigation bodies is, apparently, a necessary step to prevent the spread of the coronavirus. However, it is necessary to fully establish the means of communication between such bodies and the public and to inform the population about them. 
6 . The lack of relevant changes in the law that would suspend the pretrial investigation was another reason for the excessive workload of the courts-investigators were forced to issue extensions and judges, investigating judges were forced to consider them. In addition, due to certain quarantine restrictions, some investigative actions, such as a search of the premises, have become much more difficult or impossible. The mode of operation of public and private bodies and institutions that may be involved in the pre-trial investigation has been changed, which has slowed down the work of pre-trial investigation bodies. Thus, by analogy with Italy, it is necessary to adopt changes in legislation that would suspend the pre-trial investigation.

7. The need to involve law enforcement officers in monitoring compliance with the rules of quarantine in public transport and patrolling has once again highlighted the problem of staff shortages in law enforcement agencies. To solve this problem, it is necessary to increase funding for these structures and implement incentive programs for employees.

8. The increase in criminal liability for violating quarantine rules for only three months resulted in the demotivation of law enforcement agencies and the excessive workload of pre-trial and judicial institutions. In the future, when making appropriate changes in the legislation, the legislator needs to more carefully assess all the positive and negative aspects of such changes and take into account the possible consequences.

Thus, it can be stated that in times of the Covid-19 pandemic, in order to ensure human rights and eliminate all the negative consequences of their forced restriction, the legislator must not only quickly and decisively amend the legislation, but also do so carefully, anticipating all possible negative consequences. In addition, it is obvious that the prolonged delay in the socalled digitalization of courts has a negative impact on ensuring the basic principles of criminal proceedings. 


\section{REFERENCES}

Bars. (2020). "In such circumstances, it is simply impossible to plan something"-a police investigator on how the coronavirus interferes with the investigation of murders. ГРАТИ. In https://graty.me/uk/monologue/v-takih-usloviyah-chto-toplanirovat-prosto-nevozmozhno-sledovatel-policzii-o-tom-kak-koronavirusmeshaet-rassledovaniyu-ubijstv/.

Chawinga, W. D., Chawinga, C., Khumbo Kapondera, S., Chipeta, G. T., Majawa, F. \& Nyasulu, C. (2019). Towards e-judicial services in Malawi: Implications for justice delivery. The electronic journal of information systems in developing countries, 82(2). In https://onlinelibrary.wiley.com/doi/full/10.1002/isd2.12121.

Chernychenko, I. V. (2013). Peculiarities of realization of separate bases of criminal proceedings of Ukraine during application of video conference. Criminal law and criminology, 4, 332-336. In http://www.irbis-nbuv.gov.ua/cgibin/irbis_nbuv/cgiirbis_64.exe?C21COM=2\&I21DBN=UJRN\&P21DBN=UJR N\&IMAGE_FILE_DOWNLOAD=1\&Image_file_name=PDF/Chkup_2013_4_ 82.pdf.

Convention for the Protection of Human Rights and Fundamental Freedoms as amended by Protocols $\mathrm{n}^{\circ} 11$ and 14 (1950).

Economic truth. (2019). The number of Internet users in Ukraine increased by 7\%. In https://www.epravda.com.ua/rus/news/2019/10/11/652498/.

Fisyn, V. \& Kostrikova, E. (2020). Quarantine proceedings. Legal Newspaper. In https://yur-gazeta.com/publications/practice/inshe/karantinnesudochinstvo.html.

Jennings, W.G. \& Perez, N.M. (2020). The Immediate Impact of Covid-19 on Law Enforcement in the United States. Nature Public Health Emergency Collection, 6, 1-12. In https://www.ncbi.nlm.nih.gov/pmc/articles/PMC7275851/.

Legal Newspaper. (2020). Life goes on, or as the courts continue to operate under quarantine. In https://yur-gazeta.com/golovna/zhittya-trivae-abo-yak-sudiprodovzhut-pracyuvati-v-umovah-karantinu.html.

Nazaruk, O.I. \& Kovaleva, R.Y. (2017). Videoconferencing mode in criminal proceedings: advantages and disadvantages. Criminal law and criminology, 1, 307-311. In http://nbuv.gov.ua/j-pdf/Chkup_2017_1_69.pdf.

Russian Federation. (2020). On Amendments to the Criminal Code and Articles 31 and 151 of the Criminal Procedure Code of the Russian Federation: Law 100-FZ. In http://publication.pravo.gov.ru/Document/View/0001202004010073?index=1\& rangeSize $=1$.

Safir, F. (2020). History of court videoconferences in Ukraine. Legal Newspaper Online. In https://yur-gazeta.com/publications/practice/sudova-praktika/istoriyasudovih-videokonferenciy-v-ukrayini.html. 
Serdyuk, L.R. (2016). Regulatory and legal support for the introduction of electronic justice in Ukraine. Young scholar, 3(30), 500-505. In http://molodyvcheny.in.ua/files/journal/2016/3/118.pdf.

Shapran, K. (2020). The status of criminal proceedings - "in quarantine": the results of the first month. In https://thepage.ua/ua/experts/status-kriminalnogoprovadzhennya-na-karantini.

Suk, A. (2019). Pre-trial investigation: problems in the activity of an investigating judge. Gazeta Sug. In https://sud.ua/ru/news/publication/138321-dosudoverozsliduvannya-problemi-u-diyalnosti-slidchogo-suddi.

Turanjanin, V. \& Radulovic, D. (2020). Coronavirus (Covid-19) and Possibilities for Criminal Law Reaction in Europe: A Review. Iranian Journal of Public Health, 49, 4-11. In https://www.researchgate.net/publication/340983448_Coronavirus_Covid19_and_Possibilities_for_Criminal_Law_Reaction_in_Europe_A_Review.

Ukraine. (1991). Commercial Procedural Code of Ukraine: Law 1798-XII. In https://zakon.rada.gov.ua/laws/show/1798-12.

Ukraine. (1996). Constitution of Ukraine. In https://zakon.rada.gov.ua/laws/show/254\%D0\%BA/96-\%D0\%B2\%D1\%80. 10.

Ukraine. (2004). Civil Procedure Code of Ukraine: Law 1618-IV. In https://zakon.rada.gov.ua/laws/show/1618-15.

Ukraine. (2005). Code of Administrative Procedure of Ukraine: Law 2747-IV. In https://zakon2.rada.gov.ua/laws/show/2747-15.

Ukraine. (2012). Criminal Procedure Code of Ukraine: Law 4651-VI. In https://zakon.rada.gov.ua/laws/card/4651-17.

Ukraine. (2016). On the judiciary and the status of judges: Law 1402-VIII. In https://zakon.rada.gov.ua/laws/show/1402-19.

Ukraine. (2020). Electronic court. What it is? In the official website: https://wiki.court.gov.ua/pages/viewpage.action?pageId=6848551.

Ukraine. (2020). On Amendments to Certain Legislative Acts of Ukraine Aimed at Providing Additional Social and Economic Guarantees in Connection with the Spread of Coronavirus Disease (Covid-19): Law 540-IX. In https://zakon.rada.gov.ua/laws/show/540-20

Ukraine. (2020). On Amendments to Certain Legislative Acts of Ukraine Aimed at Preventing the Occurrence and Spread of Coronavirus Disease (Covid-19): Law 530-IX. In https://zakon.rada.gov.ua/laws/show/530-20\#Text.

Ukraine. (2020). On Amendments to Paragraph 20-5 of Section XI "Transitional Provisions" of the Criminal Procedure Code of Ukraine on the peculiarities of judicial control over the rights, freedoms and interests of persons in criminal proceedings and consideration of certain issues during court proceedings for the period of quarantine The Cabinet of Ministers of Ukraine in order to prevent the spread of coronavirus disease (Covid-19): Law 558-IX. In https://zakon.rada.gov.ua/laws/show/558-20\#Text. 
Ukraine. (2020). On protection of the population from infectious diseases: Law 1645-III. In https://zakon.rada.gov.ua/laws/show/1645-14.

Ukraine. Cabinet of Ministers. (2020). On prevention of the spread of coronavirus Covid19 on the territory of Ukraine: Resolution 211 . In https://www.kmu.gov.ua/npas/pro-vnesennya-zmin-do-postanovi-kabinetuministriv-ukrm020420ayini-vid-11-bereznya-2020-r-211.

Ukraine. Chairman of the Council of Judges. (2020). Letter 9rs-186/20. In http://rsu.gov.ua/uploads/news/no9rs-18620-vid-16032020-verhovn92b86c6546.pdf.

Ukraine. Communication Department of the National Police. (2020). In megacities one police investigator investigates 300 criminal proceedings. In https://mvs.gov.ua/ua/news/20954_U_megapolisah_odin_slidchiy_policii_rozsl idu_300_kriminalnih_provadzhen__Maksim_Cuckiridze.htm.

Ukraine. High Council of Justice. (2020). On access to justice in the context of the SARS$\mathrm{CoV}-2$ coronary virus pandemic of acute respiratory disease Covid-19: Decision. In https://court.gov.ua/press/news/916824/.

Ukraine. Ministry of Internal Affairs of Ukraine. (2017). On the organization of investigative units of the National Police of Ukraine: Order 570. In https://zakon.rada.gov.ua/laws/show/z0918-17\#Text.

Ukraine. National Anti-Corruption Bureau. (2020). The work of NABU public receptions and personal reception of citizens has been temporarily suspended. In https://nabu.gov.ua/novyny/robotu-gromadskyh-pryymalen-nabu-ta-osobystyypryyom-gromadyan-tymchasovo-pryzupyneno.

Ukraine. Office of the Prosecutor General. (2020). On April 30, the pilot of the eCase system of electronic criminal proceedings will start in the anti-corruption bodies. In https://www.gp.gov.ua/ua/news?_m=publications\&_c=view\&_t=rec\&id=27037 4.

Ukraine. Prosecutor General. (2020). On suspension of carrying out personal reception of citizens: the Order 147. In https://www.gp.gov.ua/ua/iord?_m=publications\&_t=rec\&id=262782.

Ukraine. Prosecutor General's Office. (2020). Report on criminal offenses in the country for 2020. In https://old.gp.gov.ua/ua/stst2011.html?dir_id=114140\&libid=100820\&c=edit\& _c=fo\#.

Ukraine. State Judicial Administration. (2018). On testing the subsystem "Electronic Court" in local and appellate courts began operation of the subsystem "Electronic Court" in test mode: Order. In https://dsa.court.gov.ua/userfiles/media/628_18.pdf.

Ukraine. State Judicial Administration. (2020). On amendments to the Procedure for working with technical means of videoconferencing during a court hearing in 
administrative, civil and commercial proceedings with the participation of the parties outside the courtroom: Order 196. In https://dsa.court.gov.ua/dsa/.

Ukraine. State Judicial Administration. (2020). On the introduction into the trial operation of the subsystems Electronic Court and Electronic Cabinet: Order 247. In https://dsa.court.gov.ua/dsa/inshe/14/N_247_20.

Ukraine. Supreme Court of Ukraine. (2010). On some issues that arise during the consideration by the courts of Ukraine of complaints against the decisions of the bodies of inquiry, investigator, prosecutor on the initiation of a criminal case: Resolution 6. In https://zakon.rada.gov.ua/laws/show/v0006700-10\#Text.

Ukraine. Zhovtnevyi District Court. (2020). Decision 212/5119/20. In http://reyestr.court.gov.ua/Review/91046694.

United Nations. (1955). Standard Minimum Rules for the Treatment of Prisoners. In https://www.unodc.org/pdf/criminal_justice/UN_Standard_Minimum_Rules_fo r_the_Treatment_of_Prisoners.pdf.

United Nations. (1988). Body of Principles for the Protection of All Persons under Any Form of Detention or Imprisonment: General Assembly Resolution 43/173. In https://www.ohchr.org/EN/ProfessionalInterest/Pages/DetentionOrImprisonme nt.aspx.

Universal Declaration of Human Rights. (1948). In https://zakon.rada.gov.ua/laws/show/995_015. 